\title{
Main Characteristics for Materials Used as Synthetic Surgical Meshes
}

\author{
DANUT VASILE ${ }^{1,2}$, GEORGE IANCU ${ }^{3,4 *}$, RALUCA CLAUDIA IANCU ${ }^{1,4}$, DRAGOS VIRGIL DAVITOIU ${ }^{1,2}$ \\ ${ }^{1}$ Carol Davila University of Medicine and Pharmacy, Faculty of Medicine, Department of General Surgery, 37 Dionisie Lupu Str., \\ 020021, Bucharest, Romania \\ 2Emergency University Hospital Bucharest, First Department of General Surgery, 169 Splaiul Independentei, Bucharest, Romania \\ ${ }^{3}$ Carol Davila University of Medicine and Pharmacy, Faculty of Medicine, Department of Obstetrics and Gynecology, 37 Dionisie \\ Lupu Str., 020021, Bucharest, Romania \\ ${ }^{4}$ Filantropia Clinical Hospital, Department of Gynecology, 11-13 Ion Mihalache, Bucharest, Romania
}

\begin{abstract}
Synthetic meshes are steadily developed and optimized to provide the best biocompatibility, resistance and elasticity with minimal side effects when used in vivo. This article presents mesh parameters, which influence the biological outcomes in surgical cases. Material, structure, resistance to the applied force, elasticity and biocompatibility are listed below in order to clarify the advantages and shortcomings of different mesh types. Future developments in synthetic mesh industry are presented as well in order to improve mesh acceptability in vivo and optimize healing process. There is no ideal mesh, but only prostheses with fewer side effects when correctly used, in accordance with patient needs.
\end{abstract}

Keywords: synthetic mesh, material, structural properties, mechanical properties

Synthetic meshes were used to reinforce weak areas usually at the level of abdominal wall (hernias) or genital hiatus (genital prolapse or urinary incontinence) since 1958 , and are now thought-out as a standard practice in treatment of this kind of defects [1]. Synthetic meshes are used for the purpose to mechanically seal the defect and/ or to promote scar tissue formation in order to embody the prosthesis into the surrounding tissue [2]. The present article aims to review the principal mesh parameters involved in the optimal choice of synthetic prosthesis regarding fabric, structure, resistance to the applied force, elasticity or biocompatibility.

Different synthetic and biologic meshes were used but it was mainly polypropylene material that provided the best results. There were various materials used, like polyethylene terephthalate, polyvinylidene fluoride, expanded polytetrafluoroethylene, but none of them was found to be an optimal solution. The main parameters taken into account when assessing the mesh in biological settings were pore size, shape and mesh density. Polypropylene was apparently the best tolerated synthetic material in vivo, with good resistance in time, acceptable elasticity and mild inflammatory response from the host. Actually, the target for the ideal mesh is to allow mostly soft tissue ingrowth and minimal rigid scar tissue and inflammatory infiltrates formation, providing good elasticity and tensile strength and minimal tissue rigidity $[3,4]$.

Besides biomechanical properties, biocompatibility (the host response to a prosthetic material) is one of the most important parameter taken into account when choosing the perfect mesh. In vivo mesh implant creates a foreign body inflammatory response, which promotes a chronic healing process at the interface of host tissue with the mesh, consisting of blood vessels formation and collagen deposition around mesh fibers [5]. Inflammatory response is elicited with help of macrophages migrated around mesh fibers, but also CD3+ lymphocytes, Thelper lymphocytes, cytotoxic lymphocytes, mesenchymal cells or myocytes according to a study of Klinge et al [6]. Inflammatory cellular infiltrates are followed by local collagen deposition or fibroplasia, with an initial increase in type III collagen and thereafter after the first three weeks with type I collagen being found in higher amount compared with type III collagen [7]. Biocompatibility of synthetic mesh material and the amplitude of inflammation influence the wound healing and clinical performance. Foreign body response if excessive is followed by prolonged inflammation, increased scar formation, increased rigidity of the normal tissue, shrinkage, deformation and increased stiffness with bad clinical outcome [8]. Healing mostly with tissue ingrowth and less scarring leads to better clinical outcome. A prospective animal study assessing the strength of tissue attachment variation in time from the insertion demonstrated that in the first 2 weeks is built most of the strength and tissue ingrowth and it increases slowly thereafter until 12 weeks after insertion [9].

\section{Experimental part}

\section{Material groups for surgical meshes}

Polypropylene mesh. Polypropylene dominates the surgical meshes fabric market, with over 1 million meshes used every year globally $[10,11]$. Polypropylene is a hydrophobic polymer, comprising carbon atoms with alternating methyl moieties. This fabric is inert, biocompatible, flexible but very resistant. It withstands infection and is rapidly embodied into the surrounding tissue [12]. Due to its low price and aforementioned characteristics, polypropylene meshes are most widely used [13,14] (fig. 1).

Polyvinylidene fluoride mesh. Polyvinylidene fluoride was introduced for the first time in 2002 as a promising material for surgical prosthesis [15]. Polyester and polypropylene are more prone to degradation and hydrolysis compared to polyvinylidene fluoride [16,17]. Mechanically speaking it is highly stable and it was shown to maintain $92.5 \%$ of its original strength even after 9 years [16].

*email: klee_ro@yahoo.com: Phone: 0040728042044 


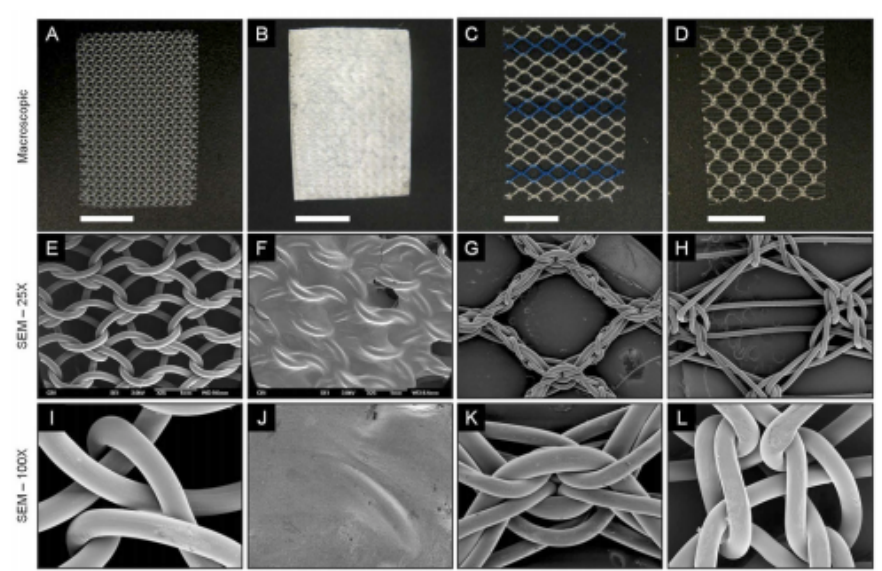

Fig. 1. Macroscopic appearance and scanning electron micrographs of mesh devices. Monofilament polypropylene mesh $(A, E, I)$,

extracellular coated monofilament polypropylene mesh $(B, F, J)$, very large pores lightweight partially absorbable mesh $(C, G, K)$, large pore monofilament polypropylene mesh $(D, H, L)$ devices were compared

macroscopically (top row - A,B,C,D) and with scanning electron

microscopy. Scanning electron micrographs were imaged at $25 \mathrm{X}$ magnification (middle row - E,F,G,H) centered over mesh pores and at 100X magnification (bottom row - $I, J, K, L$ ) centered over mesh knots. Scale bars in macroscopic images represent $1 \mathrm{~cm}$. Illustration reproduced courtesy of John Wiley and Sons Publisher, Copyright (c) 2013 Wiley Periodicals, Inc., a Wiley

Expanded polytetrafluoroethylene mesh. Polytetrafluoroethylene, a highly hydrophobic synthetic fluoropolymer, when used as a prosthetic material does not incorporate into the surrounding tissue due to its high negative charge. This particular characteristic make polytetrafluoroethylene meshes more susceptible to infection and to anatomical defect reformation $[18,19]$. Although polytetrafluoroethylene was expanded to be upgraded, its in vivo bioreactivity is still under debate [20] .

Polyester mesh. Polyester is a carbon polymer, synthesized from alcohol and carboxylic acid [21]. Polyester surgical meshes were introduced in 1960s, but nowadays are occasionally used due to reported complications and borderline efficacy [22].

\section{Results and discussions}

Structural and mechanical properties

Textile properties

Filament structure. An increased amount of foreign body material will exacerbate the foreign-body reaction with scar tissue formation. Mesh filament diversity (monofilament or multifilament fibers) is able to induce changes in means of mesh surface and weight. Multifilament (braided) meshes comprise a larger amount of exogenous material and induce an increased host response and tissue proliferation. The monofilament diameter is crucial for biomechanical properties of the mesh. The larger the fiber diameter the stronger the monofilament, but in turn this property will decrease the biomaterial qualities (mobility, flexibility and knitting capacity). For instance a polypropylene monofilament is best knitted when it has a diameter of approximately 0.15 $\mathrm{mm}$ ( = 160 dtex) [23].

Textile characteristics consists in the pattern of the single fibers in mesh structure; woven and nonwoven fabric, knitted or warp knitted fabric are described [24]. Nonwoven texture consists in non-oriented fibers or endless fibers; these structures need bonding using thermal, chemical or mechanical agents. Woven fabric is made of several distinct threads interlaced at right angles. It can be trimmed often without disintegrating the whole structure. Knitted fabric is made of several distinct threads as well, but interlacing as consecutive rows of loops usually from single yarn system. If trimmed, it usually falls apart. Warpknitted pattern are formed of consecutive courses of loops from multiple yarn systems; they can be trimmed without risking the whole structure integrity. Most meshes used in surgery are following this pattern because they can be elastic, with large pores and able to be trimmed as well (table 1).

Porosity. Mesh porosity represents the percentage of empty to solid space in accordance to area, weight or volume.The structural mesh properties were demonstrated to have a greater impact on tissue reaction compared to the type of the polymer used [25-27]. Porosity was demonstrated to be crucial for tissue assimilation [28]. The tissue's foreign body reaction and the dynamic incorporation of the scar material can be modified by

\begin{tabular}{|c|c|c|c|}
\hline Textile pattern & Elasticity & Macropores ability & Trimming \\
\hline Non-woven & No & No & Yes \\
\hline Woven & No & No & Yes \\
\hline Knitted & Yes & Yes & No \\
\hline Warp-knitted & Yes & Yes & Yes \\
\hline
\end{tabular}

Table 1

TEXTILE PROPERTIES OF MESHES

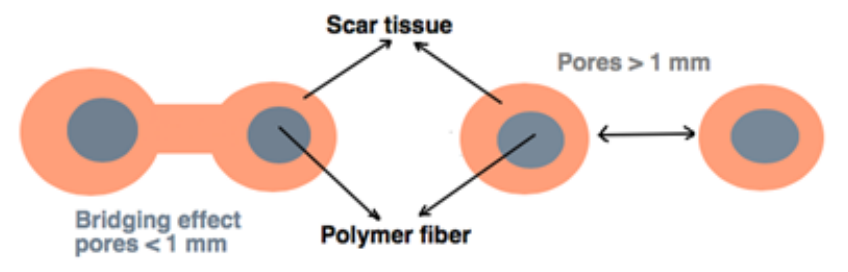

Table 2

MESH TYPE ACCORDING TO PORE SIZE [38,39]

\begin{tabular}{|c|c|}
\hline Pore type & Pore size \\
\hline Very large pore & $>2000 \mu \mathrm{m}$ \\
\hline Large pore & $1000-2000 \mu \mathrm{m}$ \\
\hline Medium pore & $600-1000 \mu \mathrm{m}$ \\
\hline Small pore & $100-600 \mu \mathrm{m}$ \\
\hline Microporous & $<100 \mu \mathrm{m}$ \\
\hline
\end{tabular}

Fig. 2. Bridging effect - scar tissue surrounds the polymer fibres and completely fills the pore space 
varying: the material's pore size, the mesh fabric, the mesh weight and the mechanical properties (fig. 1).

Fibrous tissue can breed only if the pore size is minimum 75-100 $\mu \mathrm{m}$, because this is the necessary size for making possible the access of blood vessels, collagen and fibroblasts [29]; pores with minimum size of 200-300 $\mu \mathrm{m}$ enable neovascularization [30] and those larger than 500$600 \mu \mathrm{m}$ [31] permit admission of soft tissue [21]. When pores sizes are smaller than $1 \mathrm{~mm}$, the so called bridging effect [32] can develop (fig. 2), which means that scar tissue surrounds the polymer fibres and completely fills the pore space, and are more susceptible to infection [33]. This event can result in mesh shrinkage and loss of the abdominal wall mobility. In conclusion pores smaller then $1 \mathrm{~mm}$ are predicted to scar formation and mesh shrinkage, and those larger than $1 \mathrm{~mm}$ entrap fat tissue and are called effective pores. So effective porosity defines the chances that a mesh can become entrapped in a scar, and is correlated with biocompatibility [34].

According to the pore size there are described the following types of meshes: with very large pore, with large pore, with medium pore, with small pore and microporous (table 2).

The polypropylene mesh has pore bigger than $1 \mathrm{~mm}$ in size, but if mechanical forces are applied the pore size should exceed $3 \mathrm{~mm}[34,35]$. Almost all modern prosthetic meshes are designed with initial pore size larger than 1 $\mathrm{mm}$ [36].

Lake et al evaluated the mechanical strength of polyethylene terephthalate meshes in a porcine model and found no influence of mesh density while pore size and shapes influenced significantly the tested parameters: work and work density, peak force, fracture energy and critical force. Greater tissue ingrowth and less fibrosis were observed in very large pore, medium-weight, hexagonal mesh when compared to medium pore light or medium weight meshes [37].

Shrinkage. Pores size also influences the shrinkage properties of the mesh. Shrinkage process is determined by the scar tissue constriction, which was demonstrated to be of approximately $60 \%$ of the initial wound surface $[25,34]$.

Weight. This parameter is directly dependent on pore size (which gives material quantity or density), the type of the polymer used (polymer molecular weight, fibre diameter) and textile structure. Prosthetic meshes were classified accordingly to their density in three main categories: lightweight (LW), medium weight (MW) and heavy weight (HW) $[40,41]$. Titanium/propylene meshes represent the new era of abdominal/pelvic wall prosthetic materials. They are called ultra-lightweight meshes and are associated with more rapid recovery and less longterm complications [42]. Their characteristics are listed in the table below (table 3).

Heavyweight (usual density about $100 \mathrm{~g} / \mathrm{m}^{2}-1.5 \mathrm{~g}$ for $10 \times 15 \mathrm{~cm}$ mesh) meshes are extremely strong (high tensile strength) due to their small pores, thick polymers and larger surface areas. They enable serious tissue reaction and scar formation, generating stiffness [44].

On the other hand, lightweight meshes (usual density $35 \mathrm{~g} / \mathrm{m}^{2}-0.5 \mathrm{~g}$ for $10 \times 15 \mathrm{~cm}$ mesh) have large pores (>1 $\mathrm{mm})$, thinner filaments and smaller surface areas. They determine a reduced tissue reaction promoting elasticity [44]. These characteristics grant lightweight meshes to suppress scar formation yet preserving ample mechanical strength.

Nowadays ultra-lightweight and lightweight meshes represent the standard material type used for prosthesis $[45,46]$.

Mechanical parameters. When mechanical load is applied, mesh porosity substantially decreased, with values near $90 \%$, while application of higher forces decreased porosity almost to $0 \%$; under pressure meshes during healing period mighthave therefore unfavorable conditions for tissue ingrowth, promoting enhanced foreign body inflammatory response $[47,48]$.

Textile properties influence the strength of mesh, along with filament structure (multi- or mono-filament) and polymer type. Knitted type is usually more flexible due to the possibility of larger pores in its structure, while woven meshes have lower elasticity and higher resistance to tension. Woven meshes can be stretched only on one direction, oblique to the perpendicular fibers, while knitted meshes manifest the capacity of being stretched on all directions. Depending on the mechanical behavior, meshes with anistropic stretchability should be inserted with most distensible axis perpendicular on tension lines to avoid overdistension, bulging or recurrence of parietal defect $[48,49]$.

When evaluating mechanical parameters, it has to be taken into account synthetic polymer material properties and the textile design. The American Society of Testing Materials has given several definitions for the principal mechanical mesh properties, namely elasticity, stiffness, burst and tensile strength [50]. They are detailed in table 4.

Maximum tensile load that can be applied at different sites of abdominal wall was evaluated by different authors. Rectus sheath, linea alba, inguinal area or scar tissue of a median laparotomy were assessed concerning peak pressure durina different physical activities or physiological

\begin{tabular}{|c|l|}
\hline Mechanical property & \multicolumn{1}{c|}{ Definition } \\
\hline Elasticity & $\begin{array}{l}\text { - Elastic elongation defines the property of a material to change its shape and } \\
\text { size under the action of a force and to recover the original status after removing } \\
\text { the force }\end{array}$ \\
Stiffness & $\begin{array}{l}\text { - Ratio of steadily variation of applied force on an elastic material to the } \\
\text { resulting deformation generated }\end{array}$ \\
Burst strength & $\begin{array}{l}\text { Maximum uniformly distributed pressure applied at right angle on surface } \\
\text { unit, withstand by the material under standard conditions (Pascal per squared } \\
\text { centimeter; Pa/cm2) }\end{array}$ \\
Tensile strength & $\begin{array}{l}\text { - Maximum force applied to a material unit without breaking it (Newton per } \\
\text { centimeter } \mathrm{N} / \mathrm{cm} \text { ) }\end{array}$
\end{tabular}

Table 4 MECHANICAL PROPERTIES AFTER ASTM (ACTIVE STANDARD ASTM D4850) 
situations (coughing, sneezing) or experimental tensile load applications on fresh cadavers. Cobb et al determined intraabdominal pressure in healthy adults during different daily tasks like standing, sitting, bending, coughing, Valsalva. Highest values were measured during coughing and jumping (107.6 mmHg and $171 \mathrm{mmHg}$ respectively); at risk for abdominal wall hernia are mainly high BMI patients with chronic cough that generate constant high intraabdominal pressures [51]. An early study of Williams et al measured maximum tensile forces at the level of abdominal wall after hernia surgery on vertical and horizontal load axis. On the cranio-caudal direction was found a maximum force of $22 \mathrm{~N} / \mathrm{cm}$, while on lateral direction - $32 \mathrm{~N} / \mathrm{cm}$ [52]. Inguinal hernia repair studies provided information on the forces load in the groin. A maximum of $16 \mathrm{~N} / \mathrm{cm}$ loading force is cited as acceptable [53]. Knowing normal load forces during daily activity is important to choose the appropriate mesh to correct parietal defects. Lightweight meshes exhibit better elasticity when compared with heavyweight meshes during regular daily activity. An inadequate tensile strength of the inserted mesh might lead to mesh, and implicit abdominal wall, inability to normally stretch with poor functional outcome. At loading forces of $16 \mathrm{~N} / \mathrm{cm}$, lightw eight meshes show significantly better elastic properties compared with heavyweight meshes (20-30\% compared with 5-15\% respectively) [25]. Initially, synthetic meshes were designed to have unnecessary resistance to high loading forces up to $100 \mathrm{~N} / \mathrm{cm}$, which are not encountered usually in vivo and brought poor clinical outcomes [54]. On the other hand, if elasticity is excessive, with elongation rates over $30 \%$, the repair is more prone to recurrence and loss of functional outcome [55]. At $16 \mathrm{~N} /$ $\mathrm{cm}$ loading force, mean elasticity at the level of abdominal wall on all directions were between $11 \%$ and $32 \%$ [56].

Mechanical properties of meshes have to be well defined and taken into account in order to identify the appropriate prosthesis for the patients. While isotropic meshes can be used regardless of the orientation when inserted in vivo, anisotropic meshes have to be correctly positioned considering tension lines and physiological stretch of the abdominal wall.

Future developments. Synthetic meshes are steadily developed and optimized to provide the best biocompatibility, resistance and elasticity with minimal side effects. These goals are approached by limiting as much as possible foreign body response while promoting ingrowth of tissue and vascularization with less scar formation, less rigidity and better elasticity. Materials development for in vivo use shifted in time from passive, inertfabric to active materials able to interact and influence tissue regeneration process. Cells, drugs or materials with better properties are increasingly researched and used within the synthetic matrix [43].

Mesh surface coating. Surface mesh coating is designed to reduced inflammation and foreign body response. Excessive scarring due to abundant fibrosis after chronic inflammatory response determines often complications, like reduced mobility or discomfort. Coating with collagen, polyethylene glycol, extracellular matrix, chitosan are examples of materials used to improve mesh integration in vivo, tissue ingrowth and neovascularization [57-59]. When heavyw eight meshes were coated with extracellular matrix they behaved as lightweight meshes leading to promising results of this technique due to reduced foreign body response $[57,60]$. Extracellular matrix coating of polypropylene meshes decreased the number of M1 macrophages around mesh matrix and the amount of type
I collagen fibers deposition, with less scarring, compared with uncoated meshes [61].

Stem cell pre-seeding. The healing process generated around the mesh after insertion is helped by autologous stem cells loaded on mesh surface. Autologous bonemarrow derived mesenchymal stem cells were seeded by Zhao et al on a decellularized dermal scaffold for an abdominal hernia repair in an animal model. Cell-seeded implants proved better healing with good angiogenesis and absent hernia after the repair [62]. Another study showed improved biocompatibility of polyglactin mesh after bone marrow stem cells coating in rat model [63].

Drug use. Mesh infection and subsequent erosion or vicious healing is an important concern when synthetic prostheses are used. Infection of synthetic prosthesis compromises usually the whole repair and challenges the clinical outcome of future repairs as well. Several antibiotics have been used for mesh coating. Ciprofloxacin and chitosan or vancomycin soaked meshes had a significant better bacterial clearance and reduces methicillin-resistant Staphylococcus aureus [64]. Various antimicrobial peptides have been researched as well lysozyme, human cathelicidin, human beta defensin or lysostaphin were used to cover synthetic meshes of polypropylene and antimicrobial activity against Staphylococcus aureus measured. Lysostaphin had best antibacterial activity at mesh surface [65]. More often, infection of mesh occurs after open surgery compared with laparoscopic approach as well as after multifilament, heavyweight mesh use compared with monofilament, low-w eight meshes [66]. Promising results were obtained on animal models with a polypropylene mesh treated with growth factors and poly-caprolactone nano-fibers [67].

At last, the future of parietal wall defect repair with synthetic prostheses is customizing the meshes to fit best wound area and its requirements. Because abdominal wall has anisotropic characteristics, there is still a lot to improve the isotropic meshes currently used for hernia repair. Active elements, like antibiotics, coating with biocompatible materials to improve mesh acceptability in vivo and optimize healing process should be taken into account as well to obtain better clinical outcomes.

\section{Conclusions}

Material mesh characteristics should be taken into account when choosing the appropriate mesh for a given patient. The material characteristics, the mechanical properties and the biocompatibility are critical parameters for surgical success, for minimizing postoperative complications and for avoiding hernia recurrence. The adverse events are preventable and the surgeon must pay attention to the synthetic mesh material properties. We conclude that there is no ideal mesh, but only prostheses with fewer side effects when correctly used in accordance with patients needs. Future material developments will help surgeons to achieve the best outcome for their patients.

\section{References}

1. BURGER, J.W., LUIJENDIJK, R.W., HOP, W.C., HALM, J.A., VERDAASDONK, E.G.G., JEEKEL, J. Long-term follow-up of a randomized controlled trial of suture versus mesh repair of incisional hernia. Annals of Surgery; 2004, 240: 578-585.

2. KLOSTERHALFEN, B., KLINGE, U., SCHUMPELICK, V. Functional and morphological evaluation of different polypropylene-mesh modifications for abdominal wall repair. Biomaterials;1998, 19: 22352246. 
3. HAMER-HODGES, D.W., SCOTT, N.B. Surgeon's workshop. Replacement of an abdominal wall defectusing expanded PTFE sheet (Gore-tex). J R Coll Surg Edinb; 1985, 30: 65-67.

4. MINNS, R.J ., SELMIA, M.I.A. Biomaterials: Structural and mechanical aspects of prosthetic herniorrhaphy. In: BENDAVID, R., ABRAHAMSON, J., ARREGUI, M.E., FLAMENT, J .B., PHILLIPS, E.H., editors. Abdominal Wall Hernias: Principles and Management. New York: Springer; 2001, pp 208-220.

5. KLINK, C.D., BINNEBOSEL, M., KAEMMER, D., SCHACHTRUPP, A., FIEBELER, A., ANUROV, M., SCHUMPELICK, V., KLINGE, U. Comettail-like inflammatory infiltrate to polymer filaments develops in tension-free conditions. Eur Surg Res. 2011; 46(2): 73-81.

6. KLINGE, U.,DIETZ, U., FET, N., KLOSTERHALFEN, B. Characterization of the cellular infiltrate in the foreign body granuloma of textile meshes with its impact on collagen deposition. Hernia. 2014, Aug;18(4): 571-578.

7. VAZ, M., KREBS, R.K., TRINDADE, E.N., TRINDADE, M.R. Fibroplasia after polypropylene mesh implantation for abdominal wall hernia repair in rats. Acta Cir Bras. 2009, Jan-Feb; 24(1): 19-25.

8. STERNSCHUSS, G., OSTERGARD, D.R., PATEL, H. Post-implantation alterations of polypropylene in the human. J Urol. 2012, Jul;188(1): 27-32.

9. MAJERCIK, S., TSIKITIS, V., IANNITTI, D.A. Strength of tissue attachment to mesh after ventral hernia repair with synthetic composite mesh in a porcine model. Surg Endosc. 2006, Nov; 20(11): 1671-1674. 10. COBB, W.S., KERCHER, K.W., HENIFORD, B.T. Laparoscopic repair of incisional hernias. Surg Clin North Am, 2005; 85: 91-103.

11. TODROS, S., PAVAN, P.G., PACHERA, P., NATALI, A.N. Synthetic surgical meshes used in abdominal wall surgery: PartII-Biomechanical aspects. J Biomed Mater Res B Appl Biomater. Dec 212015.

12. BILSEL, Y., $A B C l$, I. The search for ideal hernia repair; mesh materials and types. Int J Surg. 2012; 10(6): 317-321.

13. PROCTER, L., FALCO, E.E., FISHER, J.P., ROTH, J.S. Abdominal wall hernias and biomaterials. In: GEFEN A., editor. Bioengineering research of chronic wounds. 1st ed. Springer Berlin Heidelberg, 2009, p. 425-447.

14. COZAD, M. ., GRANT, D.A., BACHMAN, S.L., GRANT, D.N., RAMSHAW, B.J ., GRANT, S.A. Materials characterization of explanted polypropylene, polyethylene terephthalate, and expanded polytetrafluoroethylene composites: spectral and thermal analysis. J Biomed Mater Res B Appl Biomater; 2010, 94: 455-462.

15. KLINGE, U., KLOSTERHALFEN, B., OTTINGER, A.P., IUNGE, K., SCHUMPELICK, V. PVDF as a new polymer for the construction of surgical meshes. Biomaterials; 2002, 23(16): 3487-3493.

16. LAROCHE, G., MAROIS, Y., SCHWARZ, E., GUIDOIN, R., KING, M.W., PÂRIS, E., DOUVILLE Y. Polyvinylidene fluoride monofilament sutures: can they be used safely for long-term anastomoses in the thoracic aorta? Artif Organs. 1995; 19(11):1190-1199.

17. KLINK, C.D., JUNGE, K., BINNEBOSEL, M., ALIZAI, H.P., OTTO, J., NEUMANN, U.P., KLINGE, U. Comparison of long-term biocompatibility of PVDF and PP meshes. J Invest Surg. 2011;24(6): 292-299.

18. GREVIOUS, M.A., COHEN, M., JEAN-PIERRE, F., HERRMANN, G.E. Structural and functional anatomy of the abdominal wall. Clin Plast Surg; 2006, 33: 169-179.

19. BINNEBOSEL, M., VON TROTHA, K.T., JANSEN, P.L., CONZE, J., NEUMANN, U.P., JUNGE, K. Biocompatibility of prosthetic meshes in abdominal surgery. Seminars in Immunopathology; 2011, 3: 235-243. 20. MORAIS, J.M., PAPADIMITRAKOPOULOS, F., BURGESS, D.J. Biomaterials/tissue interactions: Possible solutions to overcome foreign body response. AAPS J; 2010, 12: 188-196.

21. TODROS, S., PAVAN, P.G., NATALI, A.N. Synthetic surgical meshes used in abdominal wall surgery: Part I-materials and structural conformation. J Biomed Mater Res B Appl Biomater. Dec 162015.

22. MAAREK, J.M., GUIDOIN, R., AUBIN, M., PRUD'HOMME, R.E. Molecular weight characterization of virgin and explanted polyester arterial prostheses. J Biomed Mater Res, 1984;18: 881-894.

23. GAOMING, J., XUHONG, M., DAJUN, L. Process of Warp Knitting Mesh for Hernia Repair and its Mechanical Properties FIBRES \&
TEXTILES in Eastern Europe July/September, 2005, Vol. 13, No. 3(51), 44-46.

24. ZHU, L.M., SCHUSTER, P., KLINGE, U. Mesh implants: An overview of crucial mesh parameters. World J Gastrointest Surg. 2015 Oct 27; 7(10) : 226-236.

25. KLOSTERHALFEN, B., JUNGE, K., KLINGE, U. The lightweight and large porous mesh concept for hernia repair. Expert Rev Med Devices. 2005 Jan; 2(1): 103-17.

26. BELLON, J.M.: Role of the new lightw eight prostheses in improving hernia repair. Chirugia Espanola, 2009; 85: 268-273.

27. KLINGE, U., PARK, J.K., KLOSTERHALFEN, B. 'The ideal mesh?'. Pathobiology, 2013; 80(4): 169,175.

28. COBB, W.S., PEINDL, R.M., ZEREY, M., CARBONELL, A.M., HENIFORD, B.T. Mesh terminology 101. Hernia, 2009; 13: 1-6.

29. AMID, P.K. Classification of biomaterials and their related complications in abdominal wall hernia surgery. Hernia, 1997; 1:1521.

30. COOPER, J.A., LU, H.H., KO, F.K., FREEMAN, J.W., LAURENCIN, C.T. Fiber based tissue-engineered scaffold for ligament replacement: Design considerations and in vitro evaluation. Biomaterials; 2005, 76. 26: 1523-1532.

31. MUHL, T., BINNEBOSEL, M., KLINGE, U., GOEDDERZ, T. New objective measurement to characterize the porosity of textile implants. J Biomed Mater Res B; 2008, 84: 176-183.

32. KLINGE, U., KLOSTERHALFEN, B., BIRKENHAUER, V., JUNGE, K., CONZE, J., SCHUMPELICK, V. Impact of polymer pore size on the interface scar formation in a rat model. J Surg Res, 2002; 103: 208-214. 33. MAROIS, Y., CADI, R., GOURDON, J., FATOURAEE, N., KING, M.W., ZHANG, Z., GUIDOLIN, R. Biostability, inflammatory response, and healing characteristics fluoropasssivated polyester-knit mesh in the repair of experimental abdominal hernias. Artif Organs, 2000; 24: 533543.

34. KLOSTERHALFEN, B., KLINGE, U. Retrieval study at 623 human mesh explants made of polypropylene - impact of mesh class and indication for mesh removal on tissue reaction, J ournal of Biomedical Materials Research Part B: Applied Biomaterials, 2013, vol. 101, no. 8, pp. 1393-1399.

35. GRECA, F.H., SOUZA-FILHO, Z.A., GIOVANINI, A., RUBIN, M.R., KUENZER, R.F., REESE, F.B., ARAUJ O, L.M. The influence of porosity on the integration histology of two polypropylene meshes for the treatment of abdominal wall defects in dogs. Hernia; 2008, 12: 45-49. 36. BROWN, C., FINCH, J. Which mesh for hernia repair? Annals of The Royal College of Surgeons of England. 2010; 92(4): 272-278. 37. LAKE, S.P., RAY, S., ZIHNI, A.M., THOMPSON, D.M. J r., GLUCKSTEIN, J., DEEKEN, C.R. Pore size and pore shape-but not mesh densityalter the mechanical strength of tissue ingrowth and host tissue response to synthetic mesh materials in a porcine model of ventral hernia repair. J Mech Behav Biomed Mater. 2015, Feb; 42: 186-197. 38. ABHAY, S., PANDIT, A.S., J EROME, A.H. Design of surgical mesh: an engineering perspective. Technol Health Care; 2004, 12: 51-65.

39. EARLE, D.B., MARK, L.A. Prosthetic material in inguinal hernia repair: how do I choose? Surg. Clin. North Am. 2008, 88 (1) 179-201.

40. KLINGE, U. Experimental comparison of monofile light and heavy polypropylene meshes: less weight does not mean less biological response. World J Surg; 2007, 31: 867-868.

41. COBB, W.S., BURNS, J.M., PEINDL, R.D., CARBONELL, A.M., MATTHEWS, B.D., KERCHER, K.W., HENIFORD, B.T. Textile analysis of heavy-weight, mid-weight and light-weight polypropylene mesh in a porcine ventral hernia model. J Surg Res; 2006, 136: 1-7.

42. KOCH, A., BRINGMAN, S., MYRELID, P., KALD, A. Randomised clinical trial of groin hernia repair ( with titanium-coated lightweight mesh compared with standard polypropylene mesh. ( Br J Surg; 2008, 95: 1226-1231.

43. KALABA, S., GERHARD, E., WINDER, J.S., PAULI, E.M., HALUCK, R.S., YANG J. Design strategies and applications of biomaterials and devices for Hernia repair, Bioactive Materials, Volume 1, Issue 1, 2016, September, pp 2-17. 
44 BILSEL Y., ABCI I. The search for ideal hernia repair; mesh materials and types, Int. J. Surg, 2012. 10 (6) 317-321.

45. BRINGMAN, S., CONZE, J ., CUCCURULLO, D., DEPREST, J., JUNGE, K., KLOSTERHALFEN, B., PARRA-DAVILA, E., RAMSHAW, B., SCHUMPELICK, V. Hernia repair: the search for ideal meshes, Hernia, 2010, 14 (1) 81-87.

46. O'DWYER, P.)., KINGSNORTH, A.N., MOLLOY, R.G., SMALL, P.K., LAMMERS, B., HOREYSECK, G. Randomized clinical trial assessing impact of a light- weight or heavyweight mesh on chronic pain after inguinal hernia repair, Br. ( J. Surg. 2005, 92 (2) 166-170.

47. BARONE, W.R., MOALLI, P.A., ABRAMOWITCH, S.D. Textile properties of synthetic prolapse mesh in response to uniaxial loading. Am J Obstet Gynecol. 2016, Sep; 215(3): 326. 1-9.

48. HERNANDEZ-GASCON, B., PENA, E., MELERO, H., PASCUAL, G. DOBLARE, M., GINEBRA, M.P., BELLON, J.M., CALVO, B. Mechanical behaviour of synthetic surgical meshes: finite element simulation of the herniated abdominal wall. Acta Biomater. 2011, Nov;7(11): 39053913.

49. SABERSKI, E.R., ORENSTEIN, S.B., NOVITSKY, Y.W. Anisotropic evaluation of synthetic surgical meshes. Hernia. 2011, Feb; 15(1): 47 52.

50. ASTM D4850 - Standard Terminology Relating to Fabrics and Fabric Test Methods. ASTM International, West Conshohocken, PA, 2013. 51. COBB, W.S., BURNS, J.M., KERCHER, K.W., MATTHEWS, B.D., IAMES NORTON, H., TODD HENIFORD, B. Normal intraabdominal pressure in healthy adults. J Surg Res, 2005. Dec;129(2): 231-235. 52. WILLIAMS, J.F., KIRKPATRICK, 」., SYME, G.A. Force measurement in the abdominal wall. Biomed Eng. 1975 May; 10(5): 181-183.

53. KLINGE, U., KLOSTERHALFEN, B., CONZE, J., LIMBERG, W. OBOLENSKI, B., OTTINGER, A.P., SCHUMPELICK, V. Modified mesh for hernia repair that is adapted to the physiology of the abdominal wall. Eur Surg; 1998, 164: 951-960.

54. BROWN, C.N., FINCH, J.G. Which mesh for hernia repair? Ann R Coll Surg Engl, 2010. 92 (4) 272-278.

55. DEEKEN, C.R., ABDO, M.S., FRISELLA, M.M., MATTHEWS, B.D. Physicomechanical evaluation of polypropylene, polyester, and polytetrafluoroethylene meshes for inguinal hernia repair. J Am Coll Surg, 2011; 212: 68-79.

56. JUNGE, K., KLINGE, U., PRESCHER, A., GIBONI, P., NIEWIERA, M., SCHUMPELICK, V. Elasticity of the anterior abdominal wall and impact for reparation of incisional hernias using mesh implants. Hernia 2001 5(3) 113-118.

57. WOLF, M.T., CARRUTHERS, C.A., DEARTH, C.L., CRAPO, P.M., HUBER, A., BURNSED, O.A., LONDONO, R., JOHNSON, S.A., DALY, K.A., SLAHL, E.C., FREUND, J.M., MEDBERRY, C.J ., CAREY, L.E., NIEPONICE, A., AMOROSO, N.J ., BADYLAK, S.F. Polypropylene surgical mesh coated with extracellular matrix mitigates the host foreign body response, J. Biomed. Mater. Res, 2014. Part A 102 (1) 234-246.

58. SHI, C., CHEN, W., ZHAO, Y., CHEN, B., XIAO, Z., WEI, Z., HOU, X., TANG, J., WANG, Z., DAI, J. Regeneration of full-thickness abdominal wall defects in rats using collagen scaffolds loaded with collagenbinding basic fibroblast growth factor, Biomaterials, 2011, 32 (3) 753759 .

59. PU, F., RHODES, N.NP., BAYON, Y., CHEN, R., BRANS, G., BENNE, $R$., HUNT, J.A. The use of flow perfusion culture and subcutaneous implantation with fibroblast-seeded PLLA-collagen 3D scaffolds for abdominal wall repair, Biomaterials 2010, 31 (15) 4330-4340.

60. WOLF, M.T., DEARTH, C.L., RANALLO, C.A., LOPRESTI, S.T., CAREY, L.E., DALY, K.A., CROWN, B.N., BADYLAK, S.F. Macrophage polarization in response to ECM coated poly- propylene mesh, Biomaterials, 2014,35 (25) 6838-6849.

61. FAULK, D.M., LONDONO, R., WOLF, M.T., RANALLO, C.A., CARRUTHERS, C.A., WILDEMANN, J.D., DEARTH, C.L., BADYLAK, S.F. ECM hydrogel coating mitigates the chronic inflammatory response to polypropylene mesh. Biomaterials. 2014, Oct; 35(30): 8585-8595. 62. ZHAO, Y., ZHANG, Z., WANG, J., YIN, P., ZHOU, J., ZHEN, M., CUI, W., XU, G., YANG, D., LIU, Z.. Abdominal hernia repair with a decellularized dermal scaffold seeded with autologous bone marrowderived mesenchymal stem cells, Artif. Organs 2012, 36 (3) 247-255. 63. DOLCE, C.J ., STEFANIDIS, D., KELLER, J.E., WALTERS, K.C., NEWCOMB, W.L., HEATH, I.]., NORTON, H.J ., LINCOURT, A.E., KERCHER, K.W., HENIFORD, B.T. Pushing the envelope in biomaterial research: initial results of prosthetic coating with stem cells in a rat model, Surg. Endosc. 2010, 24 (11) 2687-2693.

64. SADAVA, E.E., KRPATA, D.M., GAO, Y., NOVITSKY, Y.W., ROSEN, M.J . Does presoaking synthetic mesh in antibiotic solution reduce mesh infections? An experimental study, J. Gastrointest. Surg, 2013. 17 (3) 562-568.

65. YURKO, Y., MCDEAVITT, K., KUMAR, R.S., MARTIN, T., PRABHU, A., LINCOURT, A.E., VERTEGEL, A., HENIFORD, B.T. Antibacterial mesh a novel technique involving naturally occurring cellular proteins, Surg. Innov, 2012. 19 (1) 20-26.

66. AMID, P. Classification of biomaterials and their related complications in abdominal wall hernia surgery, Hernia 1997, 1 (1) 15-21.

67. PLENCNER, M., EAST, B., TONAR, Z., OTAHAL, M., PROSECKA, E., RAMPICHOVA, M., KREJCI, T., LITVINEC, A., BUZGO, M., MICKOVA, A., NECAS, A., HOCH, J ., AMLER, E. Abdominal closure reinforcement by using polypropylene mesh functionalized with poly-å-caprolactone nanofibers and growth factors for prevention of incisional hernia formation, Int. J. Nanomed, 2014. 9: 3263-3277.

$\overline{\text { Manuscript received: } 14.01 .2017}$ 